\title{
Effect of Low Level Laser Therapy on Local Bone Resorption During Orthodontic Treatment. A Randomized Controlled Trial
}

\author{
Efecto del Laser Terapéutico en la Reabsorción Osea Local Durante \\ Tratamientos de Ortodoncia. Un Ensayo Clínico Aleatoriamente Controlado
}

\author{
Ángela Dominguez*; Pilar León ${ }^{* *} \&$ Juan Fernando Aristizabal ${ }^{* * *}$
}

DOMINGUEZ, Á.; LEÓN, P.; ARISTIZABAL. J. F. Effect of low level laser therapy on local bone resorption during orthodontic treatment. A randomized controlled trial. Int. J. Odontostomat., 10(3):483-490, 2016.

ABSTRACT: The aim of this study was to assess whether the application of low-level laser therapy (LLLT) during the first stage of orthodontic treatment has an effect on local bone resorption and is detectable at the systemic level by measuring deoxypyridinoline levels (Pyrilinks) in urine. This was a randomized (1:1), double-blind, active-controlled, parallel-group trial. 28 adult patients who were going to start orthodontic treatment were randomly divided into the control group ( $\mathrm{n}: 13)$ and the experimental group ( $\mathrm{n}: 15)$, the latter of which received LLLT. All of the subjects underwent testing of urine samples: the first one on the day before the beginning of orthodontic treatment (T0), and the second one 5 days after bracket placement to measure Pyrilinks values ( $\mathrm{Dpd} / \mathrm{Cr}$ ) in urine. Group differences were evaluated with Student's paired t-test. At the beginning of the study, the Pyrilinks were in the normal range for $53.57 \%$ of the patients, and $46.43 \%$ had elevated values according to the normal ranges. Only taking into account the normal values at (T0), the average Pyrilinks for control group (T0) were $5.75 \pm 1.20 \mathrm{nM} / \mathrm{mM}$, (T1): $6.02 \pm 3.00 \mathrm{nM} / \mathrm{mM}$. For experimental group, (T0) was $5.71 \pm 0.72$, and it was 6.63 $\pm .73 \mathrm{in}$ (T1). There were no significant differences in the Pyrilinks changes. $(p=0.75)$. In the experimental group levels raised statistically significant $(p=0.009)$. LLLT on patients starting orthodontic treatment with normal Pyrilinks levels have a statistically significant increment on their levels 5 days post irradiation.

KEY WORDS: orthodontic movement, pyrilinks, low level laser, deoxypyridinoline, bone reorption.

\section{INTRODUCTION}

The application of Low-level laser therapy is a noninvasive alternative that has shown to be effective not only to reduce pain caused by the application of separators (Burns et al., 2001; Aihara et al., 2006; Cattaneo et al., 2009; Altan et al., 2012; Artés-Ribas et al., 2013; Bister \& Meikle, 2013) in the initial stages of treatment (Chen et al., 2011), during canine retraction (Cruz et al., 2004; d'Apuzzo et al., 2013) and following activation of orthodontic final archwires (Dominguez et al., 2012) but also to reduce the overall orthodontic treatment time (Dominguez et al., 2009; DomínguezCamacho \& Velásquez-Cujar, 2010; Doshi-Mehta \& Bhad-Patil, 2012; Domínguez \& Velásquez, 2013).
Tooth movement by orthodontic force application depends on remodeling at the periodontal ligament and alveolar bone. Orthodontic movement should be described as a continual and balanced process characterized by bone deposition and bone resorption (Evidence-Based Medicine Working Group, 1992).

Low-level laser therapy accelerates the bone remodeling process by stimulating osteoblastic and osteoclastic cell function and proliferation during orthodontic tooth movement. These effects are due to its ability to stimulate cell metabolism, angiogenesis, bone formation and osteoclastogenesis (Garnero et al.,

\footnotetext{
Professor, Department of Orthodontics, Faculty of Dentistry, Universidad del Valle, Cali. Colombia.

** Orthodontist, Department of Orthodontics, Faculty of Dentistry, Universidad del Valle, Cali. Colombia.

*** Professor, Department of Orthodontics, Faculty of Dentistry, Universidad del Valle, Cali. Colombia.

Funding.This investigation was proclaimed the winner of the internal Universidad del Valle research call for 2012. All of the funding was provided by the university dean's office.
} 
1994; Fassbender et al., 2009; Fujita et al., 2008.; Fujiyama et al., 2008; Habib et al., 2012; Genc et al., 2013).

Collagen cross-link molecules such as pyridinoline (PYD), deoxypyridinoline (DPD), and $\mathrm{N}$-terminal crosslinked peptides (NTX) have been measured in urine as indices of bone resorption (Ju et al., 1997). Deoxypyridinoline (DPD) is a derivative of hydroxypyridinium, which is released during bone resorption into the blood stream and is eliminated unmodified with urine. A further collagen-derived marker of bone resorption is the $\mathrm{C}$-terminal telopeptide of type I collagen, which is released in bone resorption and almost entirely excreted by the kidney (Kawasaki et al., 2000).

Pyridinium cross-links have proven to be specific and sensitive bone resorption markers for evaluation of metabolic bone diseases such as osteoporosis, hyperthyroidism and hyperparathyroidism (Lim et al., 1995; Marquezan et al., 2010; Kim et al., 2013; Marini et al., 2015).

The aim of this study was to assess if the effect on bone metabolism and the application of Low-level laser therapy (Ga-Al-As) in humans in the first stage of orthodontic treatment, is detectable at systemic level by measuring the levels of Deoxypyridinoline (Pyrilinks) in urine.

\section{MATERIAL AND METHODS}

This was a randomized (1:1), double-blind, active-controlled, parallel-group trial.

The study began in February 2013. 50 subjects were assessed for eligibility who attended to start corrective orthodontic treatment in the Posgraduate program of Orthodontics, School of Dentistry in Univalle University. A total of 41 patients were eligible for randomization into the study. Analized total, distribution and follow up are shown in the CONSORT (Consolidated Standards of Reporting Trials) Diagram (Fig. 1).

Randomazation was made under prior consecutive patient list submision to http:// www.random.org/lists. By a different subject from the one that made the patient intervention, patient asigment was hidden from the lab, data operator, and to the STATESMAN, and was implemented by one of the researchers. Control group patients received inactive laser aplications in order to blind this group. Laser manipulation was done by one subject for every patient.

Following randomization, 15 patients received the Low-level laser therapy and 13 formed the control group. The patients were all treated with brackets and tubes Orthos ${ }^{\mathrm{TM}}$ (Ormco, SA de CV Mexico) and initial arch wire Cu-NiTi 0.014 inch (Ormco, SA de CV Mexico ). All subjects had to be tested on urine samples, the first one, on the day before treatment (TO), and the second one, was taken 5 days after brackets and archwire placement. The final sample consisted in 15 patients as the experimental group and 13 patients as the control group.

\section{Inclusion Criteria}

- Patient with Ages between 18 to 40 years at the time of treatment.

- Patients without periodontal compromise.

- Without metabolic bone diseases.

- No history of fracture or orthopedic surgery 6 months before the study.

- No medication.

- Patients who initiated conventional orthodontic treatment in clinical orthodontic of the Universidad del Valle.

\section{Exclusion Criteria}

- Pregnancy.

- Patients with history of kidney or liver disease.

- Orthopedic Trauma during the study.

- History of orthopedic surgery or fractures less than 6 months.

- History of use of Bisphosphonates.

- Patients with Thyroid disease.

. Menopause.

Ethical Considerations. The study was part of Resolution 8430 of 1993 , by which the scientific, technical and administrative standards for the health research are set. The project was approved by the Institutional Review Committee of Human Ethics Faculty of Health, Universidad del Valle.

Laser protocol. Experimental subjects were irradiated with laser therapy PhotonLase III (DMC equipment; Sao Carlos Brazil) with wavelength of $808 \mathrm{~nm}, 80 \mathrm{~J} / \mathrm{cm}^{2}$ and $100 \mathrm{~mW}$, for 22 seconds, $1 \mathrm{~mm}$ from the gingiva following buccal surface of all teeth of both the upper arch and the lower arch and 22 seconds following the same protocol for the palatal / lingual surface. All of them were made by the same operator. 
DOMINGUEZ, Á.; LEÓN, P.; ARISTIZABAL. J. F. Effect of low level laser therapy on local bone resorption during orthodontic treatment. A randomized controlled trial. Int. J. Odontostomat., 10(3):483-490, 2016

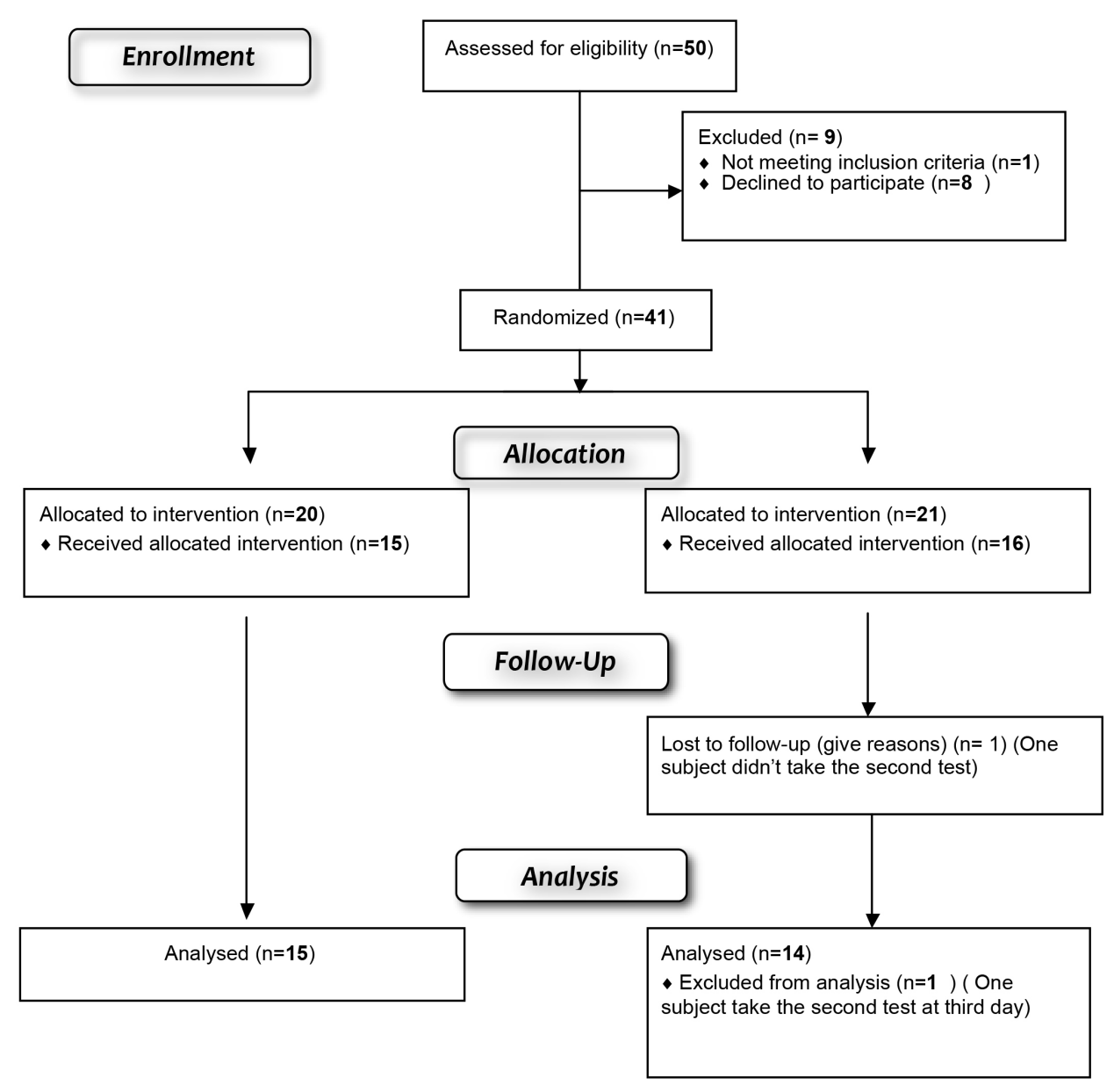

Fig. 1. Flow Diagram LLT-Pyrilinks Sample.

Evaluation of local Bone resorption. The effect on local bone resorption was evaluated by determination of Deoxypyridinoline levels in urine following this protocol:

Each sample of $30 \mathrm{ml}$ (first urine of the day) was sent to the laboratory. The sample was protected from ultraviolet light to prevent deterioration of the Deoxypyridinoline. Samples were stored at $-80^{\circ} \mathrm{C}$ until immunoassay testing according to manufacturer's instructions. The test was performed in a Sandwich Immunoassay using a monoclonal antibody as a reagent for Deoxypyridinoline (D-Pyrilinks MetranBiosystems, USA). Deoxypyridinoline in the sample competes with the Alkaline Phosphatase Deoxypyridinoline and the reaction is detected by the p-nitrophenyl phosphate substrate. Through colorimetry, the amount of color is reverse to the amount of Deoxypyridinoline sample. Following correction for urine creatinine, normal values ranging from 2.5 to $5.5 \mathrm{nM}$ of urine creatinine D-Pyr/nM for males and 2.5 to $6.5 \mathrm{nM}$ of D-Pyr/nM for female.

Two urine tests were made, one prior to the orthodontist appointment (T0) and the second 5 days post irradiation (T1).

Statistical Analysis. Data on the levels of DPD were corrected by creatinine (Deoxypyridinoline / Creatinine) and obtained in $\mathrm{nM} / \mathrm{mM}$, then they were tabulated and statistically analyzed, including age and gender with STATA software version 13 to determine the characteristics of the sample.

The changes in the levels of DPD / $\mathrm{Cr}$ in urine were compared by paired t-test because the data were parametric (no units because it is a ratio). To evaluate the difference between t0 and $\mathrm{t} 1$ in each group the Past versión 2010 Excel was used showing a normal distribution. 


\section{RESULTS}

The age average of the sample was 30.42 years $( \pm 6.24)$. Doing the Two-sample $t$ test with equal variances, it was found that the age average in the control group was 29.84 years $( \pm 8.44)$ while in the experimental group was 30.93 years $( \pm 3.6)$. No statistically significant age differences were found between groups (Table I). The distribution of participants by gender showed a percentage of $64.29 \%$ women and $35.71 \%$ for men. The age distribution in both genders was normal according to the Shapiro-Wilk test (Table II).

At the beginning of the study Pyrilinks values were in the normal range for $53.57 \%$ of the patients and $46.43 \%$ had elevated values according to the normal ranges

The Pyrilinks average levels for the control group before the procedure (experiment) (T0) were $7.45 \pm$
$2.72 \mathrm{nM} / \mathrm{mM}$ and 5 days after the experiment (T1) were $6.59 \pm 2.4 \mathrm{nM} / \mathrm{mM}$. For the experimental group (laser group) the initial values had an average of 7.59 \pm 2.92 (T0), and $7.24 \pm 1.57$ in T2 (Table III).

There were not significant differences in the Deoxypyridinoline level change comparing before and after in the control group, neither in the experimental group ( $p>0.05)$.

There were also no significant differences between groups before or after the procedure (experiment) $(p>0.05)$.

The control group showed a decrease of 69.23 $\%$ in the Pyrilinks levels and they increased in 23.08 $\%$. While in the experimental group the increase was $53.33 \%$.

Table I. Average age of the sample.

\begin{tabular}{lccrrrc}
\hline Group & Obs & Mean & Std. Err. & Std. Dev. & \multicolumn{2}{c}{ (95\% Conf. Unten/al) } \\
\hline Control & 13 & 29.84615 & 2.342052 & 8.044388 & 24.70326 & 34.94905 \\
Experimental & 15 & 30.93333 & .948516 & 3.673587 & 28.89897 & 32.9677 \\
Combined & 28 & 30.42857 & L180114 & 6.244574 & 28.00718 & 32.84996 \\
Difference & & -1.087179 & 2401903 & & -6.020361 & 3.850002 \\
\hline
\end{tabular}

diff $=$ mean $($ Control $)-$ mean $($ Experimental $) t=-0.4526$

Ho: clIff $=0$

degrees of freedom $=26$

Ha: diff $<0$
Ha: $\operatorname{diff} !=0$

Ha:diff $>\mathrm{O}$

$\operatorname{Pr}(\mathrm{T}<\mathrm{t})=0.3273 \operatorname{Pr}(\mathrm{ITI}>\mathrm{ItI})=0.6546 \operatorname{Pr}(\mathrm{T}>\mathrm{t})=0.6727$

Table II. Deoxypyridinoline Concentration (all subjects included).

\begin{tabular}{llllll}
\hline \multicolumn{4}{c}{ Control } & \multicolumn{3}{c}{ Experimental } \\
\hline T0 & Average \pm SD & $7,45 \pm 2,72$ & $\mathrm{nM} / \mathrm{mM}$ & $7,59 \pm 2,92$ & $\mathrm{nM} / \mathrm{mM}$ \\
$\mathrm{T} 1$ & Average \pm SD & $6,59 \pm 2,4$ & $\mathrm{nM} / \mathrm{mM}$ & $7,24 \pm 1,57$ & $\mathrm{nM} / \mathrm{mM}$ \\
\hline
\end{tabular}

Table III. Deoxypyridinoline Concentration for subjects with normal levels in TO.

\begin{tabular}{llllll}
\hline \multicolumn{4}{c}{ Control } & \multicolumn{3}{c}{ Experimental } \\
\hline T0 & Average \pm SD & $5,75 \pm 1,2$ & $\mathrm{nM} / \mathrm{mM}$ & $5,71 \pm 0,72$ & $\mathrm{nM} / \mathrm{mM}$ \\
T1 & Average \pm SD & $6,59 \pm 2,4$ & $\mathrm{nM} / \mathrm{mM}$ & $6,63 \pm 0,73$ & $\mathrm{nM} / \mathrm{mM}$ \\
\hline
\end{tabular}

\section{DISCUSSION}

To evaluate if the effect on bone metabolism and the LLLT is detectable in urine, Pyrilinks values were measured before the initial activation of orthodontic archwires and 5 days later, finding changes in the results of a test that should not change in such a short time, unless a procedure is done, and has an effect on 
bone turnover. In this case orthodontic treatment with or without low level laser therapy application.

This evaluation method was selected because urinary measurement of free Deoxypyridinoline (DPD) exhibits the least biological variability day-to-day, within individuals across the diurnal cycle, and within a healthy premenopausal population (Marquezan et al., 2010).

The results showed no significant difference in the level changes of Pyrilinks comparing before and after between the control and the experimental group. These results suggest that on the fifth day of starting orthodontic treatment the bone turnover is detectable in urine but due to the series of events involved after the application of an orthodontic force, probably on this day an increase occurs in the proliferation of osteoblast more than a promotion of pre osteoclasts aggregation to become osteoclasts.

At the beginning of the study, Pyrilinks values were in the normal range for $53.57 \%$ of the patients and $46.43 \%$ had elevated values according to the normal ranges. This may explain the large individual variation of the different movement speed in patients under orthodontic treatment that depends on the particular state of their bone metabolism. Some patients may have increased osteoclast activity from the beginning of their treatment which may influence the rate of tooth movement.

The results also suggest that on the fifth day of irradiation, it cannot be found an increase in osteoclastogenesis, but there can also be a predominant proliferation of osteoblasts that were previously found in irradiating normal human osteoblast cell cultures having a peak at the same day in vitro (Oppenheim, 1942), without any cytotoxic effect on the pre-osteoclasts (Reitan \& Kvam, 1971).

In the clinical trials that analyzed osteoclastogenesis (Robins et al., 1991; Sackett et al., 1996; Sarno et al., 1999) the process was detected from days 2-19, whereas Marquezan et al. did not find differences.

It is possible that day five was too early to detect an increment in osteoclastogenesis. Seibel et al. (1993) found that osteoclastogenesis was statistically significant higher than the control group on day 7 and 13. However, a significant increase in the proliferation of Osteoblasts could achieve an increase in RANKL and subsequently by the feedback this increase osteoclastogenesis, being the expression of RANKRANKL the mechanism by which the application of laser stimulates the velocity of the movement as was reported by Fujita et al. (Sousa et al., 2014).

Altan et al. (in Sousa et al., 2011) reported that LLLT accelerates the bone remodeling process by stimulating osteoblastic and osteoclastic cell proliferation and function during orthodontic tooth movement. This suggests that in terms of acceleration of dental movement, it is important to consider not only osteoclastogenesis but also the increase in the population of osteoblast necessary for an effective bone remodeling process.

The authors do not know about previous reports that have used Pyrilinks to evaluate the effects on bone metabolism, after observing that they can be changed after the application of a force. Although on day 5 not in a statistically significant way, but if is clinically important to begin understanding with a different gaze the interpretation of the biology of tooth movement different from the pressure - tension theory described over 100 years ago (Sun et al., 2001) and based on animal studies (Uebelhart et al., 1990; Tortamano et al., 2009; Sygouros \& Acar, 2013) at present these types of studies are not included on the evidence scale or are classified below expert opinion (Yamaguchi et al., 2007; Viecilli et al., 2008; Youssef et al., 2008; Yamaguchi et al., 2010) and this theory has begun to be revalued (Zhu et al., 2002) but it needs contemporary methods to be totally based on human.

So far LLLT as an accelerated treatment modality for orthodontic tooth movement is supported by the systematic review developed by Sousa et al. (2014) however it is necessary to perform more randomized controlled clinical trials to clarify the sequence of events that occur every day in the dentoalveolar bone metabolism after the application of an orthodontic force and we suggest performing Pyrilink tests on days 1,3 and 7 .

\section{CONCLUSIONS}

- LLLT on patients starting orthodontic treatment with normal Pyrilinks levels have a statistically significant increment on their levels 5 days post irradiation.

- It is suggested that measurement of Deoxipiridinoline levels in urine is a method that can be used to assess 
the changes day by day in bone metabolism which occur at the dentoalveolar bone level and can be detectable systemically.

- Not all patients starting orthodontic treatment have a normal range in levels of Deoxypyridinoline in urine, which means an increase of systemically osteoclastic activity, which may explain the large intra-individual variability in the proportion of tooth movement depending on bone metabolism.

DOMINGUEZ, Á.; LEÓN, P.; ARISTIZABAL. J. F. Efecto del laser terapéutico en la reabsorción osea local durante tratamientos de ortodoncia. Un ensayo clínico aleatoriamente controlado. Int. J. Odontostomat., 10(3):483-490, 2016.

RESUMEN: El objetivo de este trabajo fue evaluar si la aplicación de la terapia láser de bajo nivel (TLBN) durante la primera etapa del tratamiento ortodóncico tiene un efecto sobre la resorción ósea local y es detectable a nivel sistémico midiendo los niveles de desoxipiridinolina en la orina. Se trató de un ensayo aleatorizado (1:1), doble ciego, controlado de forma activa y paralelo. 28 pacientes adultos que iban a iniciar el tratamiento de ortodoncia se dividieron al azar en el grupo control (n: 13) y el grupo experimental (n: 15), el último de los cuales recibió TLBN. Todos los sujetos fueron sometidos a pruebas de muestras de orina: la primera en el día anterior al inicio del tratamiento ortodóncico (T0) y la segunda 5 días después de la colocación del bracket para medir los valores de Pyrilinks (Dpd / Cr) en la orina. Las diferencias grupales se evaluaron con la prueba t de Student pareada. Al inicio del estudio, los Pyrilinks estaban en el rango normal para $53,57 \%$ de los pacientes, y $46,43 \%$ tenían valores elevados según los rangos normales. Sólo teniendo en cuenta los valores normales en (T0), los Pyrilinks medios para el grupo de control (T0) fueron 5,75 $\pm 1,20 \mathrm{nM} / \mathrm{mM}$, (T1): 6,02 $\pm 3,00 \mathrm{nM} / \mathrm{mM}$. Para el grupo experimental, (T0) fue de $5,71 \pm 0,72$, y fue de 6,63 $\pm 0,73$ en (T1). No hubo diferencias significativas en los cambios de Pyrilinks. $(P=$ $0,75)$. En el grupo experimental los niveles aumentaron estadísticamente $(p=0,009)$. LLLT en los pacientes que comienzan el tratamiento ortodóncico con niveles normales de Pyrilinks tienen un incremento estadísticamente significativo en sus niveles 5 días después de la irradiación.

PALABRAS CLAVE: movimiento ortodóncico, pirilinks, láser de bajo nivel, desoxipiridinolina, reabsorción ósea.

\section{REFERENCES}

Aihara, N.; Yamaguchi, M. \& Kasai, K. Low-energy irradiation stimulates formation of osteoclast-like cells via RANK expression in vitro. Lasers Med. Sci., 21(1):24-33, 2006.
Altan, B. A.; Sokucu, O.; Ozkut, M. M. \& Inan, S. Metrical and histological investigation of the effects of low-level laser therapy on orthodontic tooth movement. Lasers Med. Sci., 27(1):131-40, 2012.

Artés-Ribas, M.; Arnabat-Dominguez, J. \& Puigdollers, A. Analgesic effect of a low-level laser therapy $(830 \mathrm{~nm})$ in early orthodontic treatment. Lasers Med. Sci., 28(1):33541, 2013.

Bister, D. \& Meikle, M. C. Re-examination of 'Einige Beitrage zur Theorie der Zahnregulierung' (Some contributions to the theory of the regulation of teeth) published in 19041905 by Carl Sandstedt. Eur. J. Orthod., 35(2):160-8, 2013.

Burns, P. B.; Rohrich, R. J.; \& Chung, K. C. The levels of evidence and their role in evidence-based medicine. Plast. Reconstr. Surg., 128(1):305-10, 2001.

Cattaneo, P. M.; Dalstra, M. \& Melsen, B. Strains in periodontal ligament and alveolar bone associated with orthodontic tooth movement analyzed by finite element. Orthod. Craniofac. Res., 12(2):120-8, 2009.

Chen, Y.; Cao, Z.; Zhang, L.; Xu, X.; Chen, Y. \& Chen Y. Low level laser can be a novel adjuvant method for orthodontic tooth movement on postmenopausal women. Med. Hypotheses, 76(4):479-81, 2011.

Cruz, D. R.; Kohara, E. K.; Ribeiro, M. S. \& Wetter, N. U. Effects of low-intensity laser therapy on the orthodontic movement velocity of human teeth: a preliminary study. Lasers Surg. Med., 35(2):117-20, 2004.

d'Apuzzo, F.; Cappabianca, S.; Ciavarella, D.; Monsurrò, A.; Silvestrini-Biavati, A. \& Perillo, L. Biomarkers of periodontal tissue remodeling during orthodontic tooth movement in mice and men: overview and clinical relevance. Scientific World J., 2013:105873, 2013.

Dominguez, A.; Bayona, G. \& Casas, A. In vitro response of human pre-osteoclasts to low intensity laser irradiation. J. Res. Biol., 2(8):733-41, 2012.

Dominguez, A.; Castro, P. \& Morales, M. An in vitro study of the reaction of human osteoblasts to low-level laser irradiation. J. Oral Laser Appl., 9(1):21-8, 2009.

Domínguez, A. \& Velásquez, S. A. Effect of low-level laser therapy on pain following activation of orthodontic final archwires: a randomized controlled clinical trial. Photomed. Laser Surg., 31(1):36-40, 2013.

Domínguez-Camacho, A. \& Velásquez-Cujar, S. A. Acceleration effect of orthodontic movement by application of low-intensity laser. J. Oral Laser Applications, 10(2-3):99-105, 2010. 
Doshi-Mehta, G. \& Bhad-Patil, W. A. Efficacy of lowintensity laser therapy in reducing treatment time and orthodontic pain: a clinical investigation. Am. J. Orthod. Dentofacial Orthop., 141(3):289-97, 2012.

Evidence-Based Medicine Working Group. Evidence-based medicine. Evidence-based medicine. A new approach to teaching the practice of medicine. JAMA, 268(17):2420-5, 1992.

Fassbender, W. J.; Gödde, M.; Brandenburg, V. M.; Usadel, K. H. \& Stumpf, U. C. Urinary bone resorption markers (deoxypyridinoline and C-terminal telopeptide of type I collagen) in healthy persons, postmenopausal osteoporosis and patients with type I diabetes. Adv. Med. Sci., 54(1):1-6, 2009.

Fujita, S.; Yamaguchi, M.; Utsunomiya, T.; Yamamoto, H. \& Kasai, K. Low-energy laser stimulates tooth movement velocity via expression of RANK and RANKL. Orthod. Craniofac. Res., 11(3):143-55, 2008.

Fujiyama, K.; Deguchi, T.; Murakami, T.; Fujii, A.; Kushima, K. \& Takano-Yamamoto, T. Clinical effect of $\mathrm{CO}(2)$ laser in reducing pain in orthodontics. Angle Orthod., 78(2):299-303, 2008.

Garnero, P.; Vassy, V.; Bertholin, A.; Riou, J. P. \& Delmas, P. D. Markers of bone turnover in hyperthyroidism and the effects of treatment. J. Clin. Endocrinol. Metab., 78(4):955-9, 1994

Genc, G.; Kocadereli, I.; Tasar, F.; Kilinc, K.; EI, S. \& Sarkarati, B. Effect of low-level laser therapy (LLLT) on orthodontic tooth movement. Lasers Med. Sci., 28(1):41-7, 2013.

Habib, F. A.; Gama, S. K.; Ramalho, L. M.; Cangussú, M. C.; dos Santos Neto, F. P.; Lacerda, J.A.; de Araújo, T. M. \& Pinheiro, A. L. Effect of laser phototherapy on the hyalinization following orthodontic tooth movement in rats. Photomed. Laser Surg., 30(3):179-85, 2012.

Ju, H. S.; Leung, S.; Brown, B.; Stringer, M. A.; Leigh, S.; Scherrer, C.; Shepard, K.; Jenkins, D.; Knudsen, J. \& Cannon, R. Comparison of analytical performance and biological variability of three bone resorption assays. Clin. Chem., 43(9):1570-6, 1997.

Kawasaki, K. \& Shimizu, N. Effects of low-energy laser irradiation on bone remodeling during experimental tooth movement in rats. Lasers Surg. Med., 26(3):28291, 2000.

Kim, W. T.; Bayome, M.; Park, J. B.; Park, J. H.; Baek, S. $\mathrm{H}$.; Kook, Y. A. Effect of frequent laser irradiation on orthodontic pain. A single-blind randomized clinical trial. Angle Orthod., 83(4):611-6, 2013.
Lim, H. M.; Lew, K. K. \& Tay, D. K. A clinical investigation of the efficacy of low level laser therapy in reducing orthodontic postadjustment pain. Am. J. Orthod. Dentofacial Orthop., 108(6):614-22, 1995.

Marini, I.; Bartolucci, M. L.; Bortolotti, F.; Innocenti, G.; Gatto, M. R. \& Alessandri Bonetti, G. The effect of diode superpulsed low-level laser therapy on experimental orthodontic pain caused by elastomeric separators: a randomized controlled clinical trial. Lasers Med. Sci., 30(1):35-41, 2015.

Marquezan, M.; Bolognese, A. M. \& Araújo, M. T. Effects of two low-intensity laser therapy protocols on experimental tooth movement. Photomed. Laser Surg., 28(6):75762,2010

Oppenheim, A. Human tissue response to orthodontic intervention of short and long duration. Am. J. Orthod. Dentofacial ERJ., 28(5):263-30, 1942.

Reitan, K. \& Kvam, E. Comparative behavior of human and animal tissue during experimental tooth movement. Angle Orthod., 41(1):1-14, 1971.

Robins, S. P.; Black, D.; Paterson, C. R.; Reid, D. M.; Duncan, A. \& Seibel, M. J. Evaluation of urinary hydroxypyridinium crosslink measurements as resorption markers in metabolic bone diseases. Eur. J. Clin. Invest., 21(3):310-5, 1991.

Sackett, D. L.; Rosenberg, W. M.; Gray, J. A.; Haynes, R. B. \& Richardson, W. S. Evidence based medicine: what it is and what it isn't. BMJ, 312(7023):71-2, 1996.

Sarno, M.; Powell, H.; Tjersland, G.; Schoendorfer, D.; Harris, H.; Adams, K.; Ogata, P. \& Warnick, G. R. A collection method and high-sensitivity enzyme immunoassay for sweat pyridinoline and deoxypyridinoline cross-links. Clin. Chem., 45(9):1501-9, 1999.

Seibel, M. J. ; Cosman, F.; Shen, V.; Gordon, S.; Dempster, D. W.; Ratcliffe, A. \& Lindsay, R. Urinary hydroxypyridinium crosslinks of collagen as markers of bone resorption and estrogen efficacy in postmenopausal osteoporosis. J. Bone Miner. Res., 8(7):881-9, 1993.

Sousa, M. V.; Pinzan, A.; Consolaro, A.; Henriques, J. F. \& de Freitas, M. R. Systematic literature review: influence of low-level laser on orthodontic movement and pain control in humans. Photomed. Laser Surg., 32(11):5929, 2014

Sousa, M. V.; Scanavini, M. A.; Sannomiya, E. K.; Velasco, L. G. \& Angelieri, F. Influence of low-level laser on the speed of orthodontic movement. Photomed. Laser Surg., 29(3):191-6, 2011. 
Sun, X.; Zhu, X.; Xu, C.; Ye, N. \& Zhu, H. Effects of low energy laser on tooth movement and remodeling of alveolar bone in rabbits. Hua Xi Kou Qiang Yi Xue Za Zhi, 19(5):290-3, 2001.

Sygouros, A. \& Acar, A. Evidence-based orthodontics: Appraisal of the methodologies of systematic reviews and meta-analyses in controversial areas of orthodontics. J. World Fed. Orthod., 2(3):e117-22, 2013.

Tortamano A.; Lenzi, D. C.; Haddad, A. C.; Bottino, M. C; Dominguez, G. C. \& Vigorito, J.W. Low-level laser therapy for pain caused by placement of the first orthodontic archwire: a randomized clinical trial. Am. J. Orthod. Dentofacial Orthop., 136(5):662-7, 2009.

Uebelhart, D.; Gineyts, E.; Chapuy, M. C. \& Delmas, P. D. Urinary excretion of pyridinium crosslinks: a new marker of bone resorption in metabolic bone disease. Bone Miner., 8(1):87-96, 1990.

Viecilli, R. F.; Katona, T. R.; Chen, J.; Hartsfield, J. K. Jr. \& Roberts, W. E. Three-dimensional mechanical environment of orthodontic tooth movement and root resorption. Am. J. Orthod. Dentofacial Orthop., 133(6):791.e11-26, 2008.

Yamaguchi, M.; Fujita, S.; Yoshida, T.; Oikawa, K.; Utsunomiya, T.; Utsunomiya, T. \& Yamamoto, H. \& Kasai, K. Low-energy laser irradiation stimulates the tooth movement velocity via expression of M-CSF and c-fms. Orthod. Waves, 66(4):139-48, 2007.

Yamaguchi, M.; Hayashi, M.; Fujita, S.; Yoshida, T.; Utsunomiya, T.; Yamamoto, H. \& Kasa, K. Low-energy laser irradiation facilitates the velocity of tooth movement and the expressions of matrix metalloproteinase-9, cathepsin K, and alpha(v) beta(3) integrin in rats. Eur. J. Orthod., 32(2):131-9, 2010.

Youssef, M.; Ashkar, S.; Hamade, E.; Gutknecht, N.; Lampert, F. \& Mir, M. The effect of low-level laser therapy during orthodontic movement: a preliminary study. Lasers Med. Sci., 23(1):27-33, 2008.

Zhu, X.; Chen, Y. \& Sun, X. A study on expression of basic fibroblast growth factors in periodontal tissue following orthodontic tooth movement associated with low power laser irradiation. Hua Xi Kou Qiang Yi Xue Za Zhi., 20(3):166-8, 2002.
Correspondence to:

Angela Domínguez Camacho, DDS, Orthodontist, Professor, Faculty of Dentistry

Universidad Del Valle

Calle 4a.B \# 36-00

Cali

COLOMBIA

Email: angela.dominguezc@gmail.com

Received:15-07-2016

Accepted: 17-10-2016 